\title{
SOUND PROPERTIES OF PLANINSKO POLJE (SLOVENIA)
}

\section{ZVOČNE ZNAČILNOSTI PLANINSKEGA POLJA (SLOVENIJA)}

\author{
Josip KOROŠEC ${ }^{1}$, Boštjan PEROVŠEK ${ }^{2}$, Dejan VONČINA ${ }^{3}$
}

\begin{abstract}
Josip Korošec, Boštjan Perovšek, Dejan Vončina: Sound properties of Planinsko polje (Slovenia)

Geographically, the Planinsko Polje field is one of the most preserved cultural regions of the Karstic landscape of inner Slovenia and as such a protected area of national importance. It can be recognized by its exceptional features and landmarks of material and non-material heritage and by its high-quality symbiosis of all ingredients in its space. The research of sound in the area of Planinsko Polje shows that it is an important, preserved constituent of natural and cultural heritage. Its manifestations are also interesting as indicators of its actual endangerment.

Key words: sound, non-material heritage, cultural region, protected area.
\end{abstract}

The research project 'Defining the Heritage Phenomenon' has been organized within the programme of the Institute for Conservation and Restoration of the Institute for the Protection of Cultural Heritage of Slovenia (ZVKDS) and the Notranjska Museum in Postojna since 2005. Its direct cause was the constant discoveries of new qualities and ingredients of the notion heritage itself and the increasing complexity of the conditionality of its existence, meaning and protection. In the processes of sustained changes in existing relations, it is also shown as a most sensitive area, whose properties are threatened by various, often interrelated causes. Conservation practice warns that their state depends on a large number of factors. Thus the definition of the heritage phenomena and the methods of recognizing, evaluating and defining it also brings a gradual implementation of new methods of conservation and adaptations of established ones to its core meaning.

However, heritage represents a phenomenon only if it is constantly upgraded as a notion and if it uses its humanization to encourage creativity and to find meaning for the future in the past. It also defines the understanding of the dimensions of space-time for a period, the dimensions in which its substance exists and gives it

\begin{abstract}
Izvleček
Josip Korošec, Boštjan Perovšek, Dejan Vončina: Zvočne značilnosti Planinskega polja (Slovenija)

Planinsko polje kot geografski pojem sodi med najbolj ohranjene kulturne krajine kraške krajine notranje Slovenije in s tem med varovana območja državnega pomena. Prepoznaven je po izjemnih dobrinah in znamenitostih snovne in nesnovne dediščine ter hkrati po kakovostnem sožitju vseh sestavin v svojem prostoru. Raziskave zvoka v območju Planinskega polja so pokazale, da le ta predstavlja pomembno ohranjeno sestavino naravne in kulturne dediščine. V svoji pojavnosti pa je zanimiv tudi kot pokazatelj njene dejanske ogroženosti.

Ključne besede: zvok, nesnovna dediščina, kulturna krajina, varovano območje.
\end{abstract}

its civilizational-cultural character, and also the dimensions creating the balance of relations within it or even conditions the deconstruction of its ingredients. The fact is that the notion of heritage changes drastically depending on the meaning of its completeness. Some types or protected groups ${ }^{1}$ are only now entering public awareness and receiving expert treatment, surely because of the recognition of the value of such goods, and also because of their actual involvement and essentiality as the core of the active space. The realization that some of them, such as cultural landscapes, need a more direct protection, because they are increasingly endangered, also requires a different estimate of causes and consequences of the actual states of individual types or goods.

Planinsko polje was chosen as the first research area because it was estimated that it could provide the most answers to the initial essential questions; the purpose is to use the gathered data to contribute to the valorization of the effectiveness of individual methods and of the system of protection itself - especially in the areas of prevention and intervention. Considering the size, it is a manage-

\footnotetext{
${ }^{1}$ They are individually defined by the Law on Cultural Heritage Protection, especially articles 5 and 6 .
}

\footnotetext{
${ }^{1} \mathrm{~J}$. Korošec, Institut za konservatorstvo in restavratorstvo pri Zavodu za varstvo kulturne dediščine Slovenije

${ }^{2}$ B. Perovšek, Saeta- Zavod za kulturne in promocijske aktivnosti

${ }^{3}$ D. Vončina, Notranjski muzej, Postojna

Received/Prejeto: .29.10.2007
} 


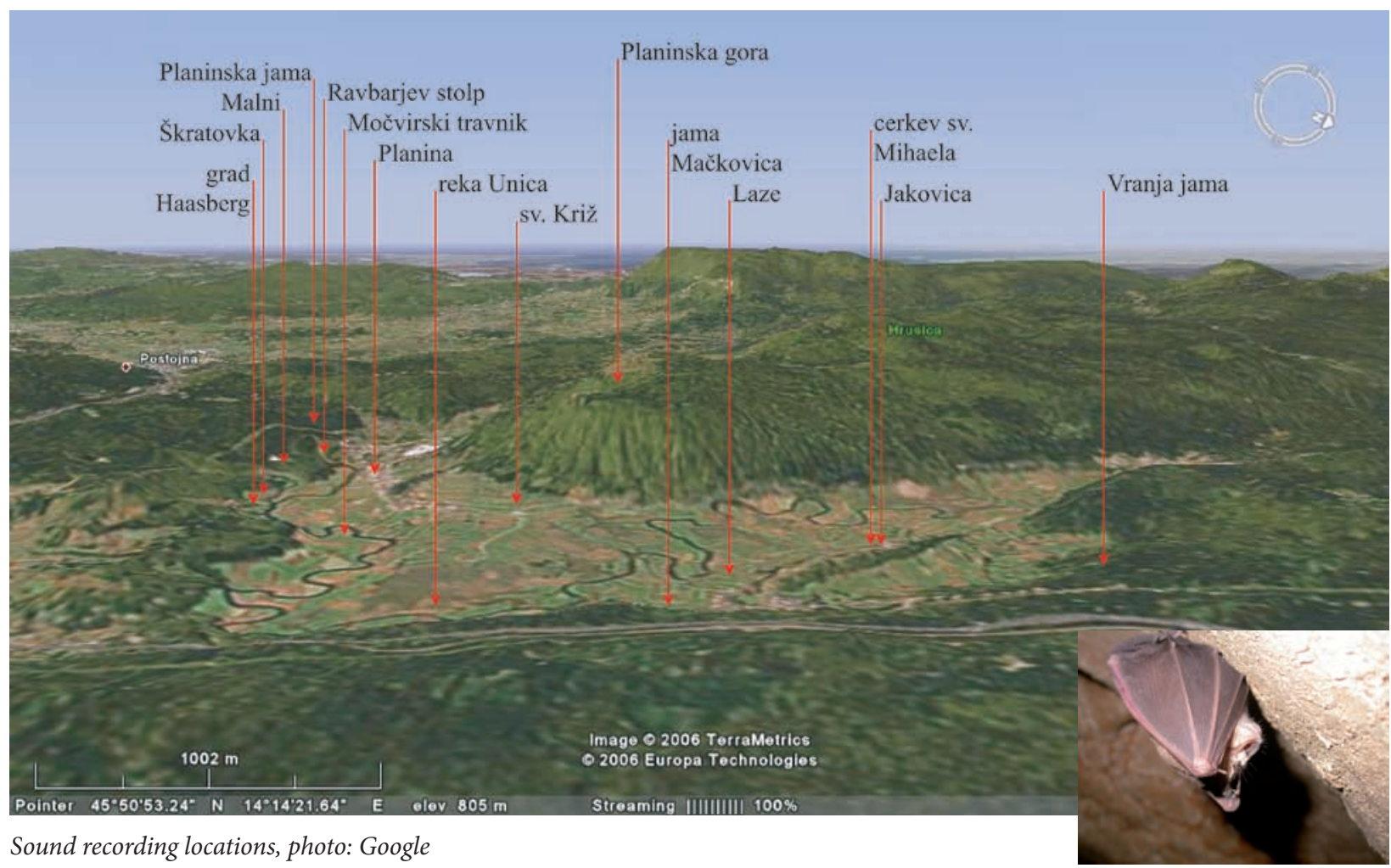

Veliki podkovnjak (Rhinolophus ferrumeqinum) Planinska Jama, photo: Slavko Polak

able area with a steady low activity of present factors, an area containing a condensed version of heritage properties similar to those in more distinctive areas and whose complete preservation points to a creative cohabitation between its natural and cultural parts and the intertwining with other values.

The articulation of methods and perfection of tools offers among other things a different perception and treatment of that part of heritage which was in the past protected only because of its exclusive existence. One of such types is also sound as a characteristic element of expression of a certain time, as a field of presence and creativity of a range of activities in a certain space or as an indicator of development and autonomy of its carriers in overcoming the endangerment presented by various factors.

That is why the Institute for Preservation and Restoration of ZVKDS and the Notranjska Museum used the programme 'Defining the Heritage Phenomenon' to present its state in Planinsko Polje; it joins the characteristics of a cultural landscape with regional creation of a natural area into a whole, which in time became a quality of national importance.

Paradoxically, we realize that a sound exists only after it stops. Sounds that surround us, or had surrounded us, are not given enough attention, so they are quickly forgotten. The disappearance of sounds is just as severe a loss for society as the disappearance of the items these sounds belong to. Some sounds will never be heard again, and some only coincidentally: manual grass scything, manual iron forging, rattling of the mills ... Such things should be archived. In some places, recording has already been undertaken. In Slovenia the 'lost' sounds only appear in individual, mostly museum exhibitions and in fragments in some sound archives of individual institutions.

Not only items, even past periods had their own sound. History books record what was happening in a certain era, allowing us to imagine the sound of the times. Sounds of each era are in tune with the period's internal life beat, which can be completely different even between villages and towns. Regions have their own distinct sounds as well. The Karst sounds different from the Littoral and the Pannonian plain; because of different activities of the inhabitants and of course because of the natural characteristics of the environment.

Sound, an ingredient of the objective world, with its presence defines space as such and is a characteristic of individual areas. It is all that makes sound; carriers or creators of sound can be classified as: direct - nature with its phenomena and humans with their activities and indirect - activities, where sound is only a negligible side effect.

Sound is a category understood and perceived as an independent phenomenon or as a constituent of 


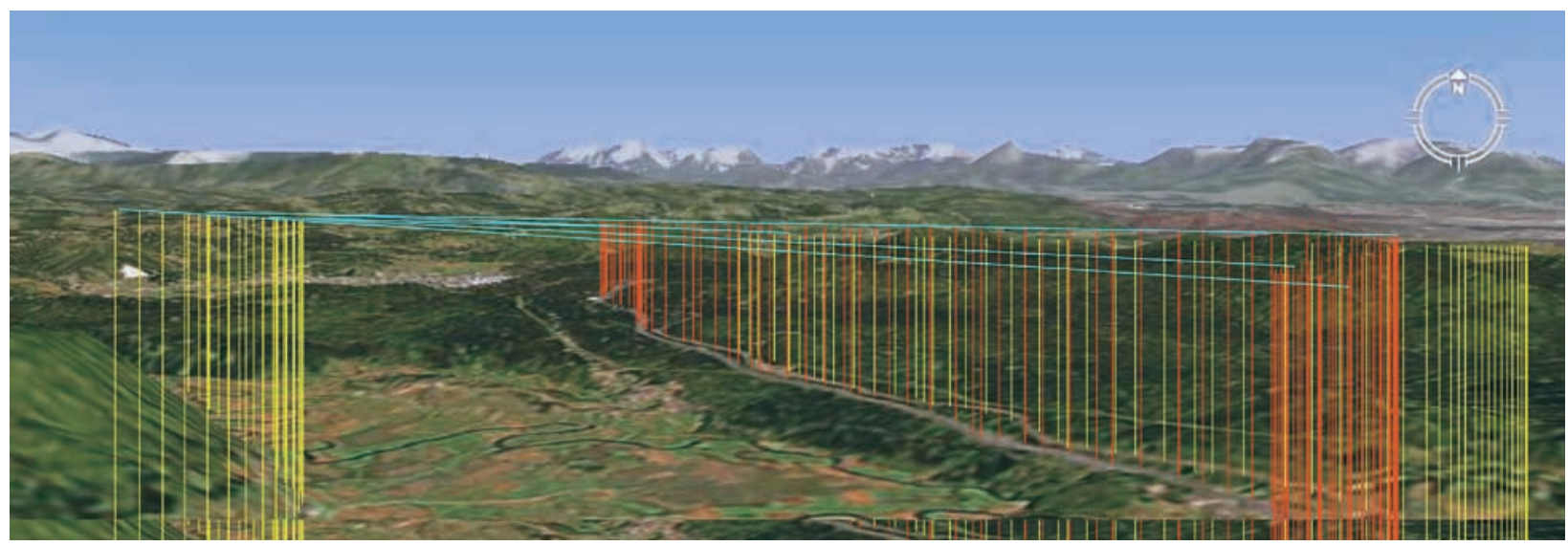

Sound sceneries endangering the space of Planinsko Polje, photo: Google

other processes. Simultaneously, sound is an intangible substance, limited in time and variously endangered. Preserving, protecting and saving its values demands a suitable integration into a system of non-material, intangible heritage ${ }^{2}$, which can transport us into sound-active, long-gone spaces.

Notionally, the field of sound as a range of sound oscillation is divided into four essentially different types: tone, timbre, noise and bang. All four are in the so-called sound field, which defines the space in which sound phenomena occur. Thus, the area of capturing and editing the sounds must be in tune or connected to the space ${ }^{3}$; the topic of research should be elements of natural and urbane environments - because that is the only way to obtain correct realizations about the origins, creation, transformation and disappearance or perseverance of sound in a specific area.

\section{The research encompasses:}

General sound phenomena: are not directly connected to a specific phenomenon and are not created only by humans with their activity and are not only a product of natural phenomena. Example: slamming: wind slamming into windows (natural phenomena) or doors or windows slamming (human phenomena)

Natural sound phenomena: are directly connected to certain natural phenomena caused by natural factors (wind, rain, snow, water, fire, rock crumbling ...) or are caused by animals ${ }^{4}$.

\footnotetext{
${ }^{2}$ Convention for the Safeguarding of Intangible Cultural Heritage, UNESCO 2003

${ }^{3}$ Miroslav Adlešič, Svet zvoka in glasbe (2. knjiga), Svet žive fizike (World of Sound and Music (2nd book), World of Living Physics), Mladinska knjiga, Ljubljana 1964, p.p.657

${ }^{4}$ M. Adlešič, pp. 356-362
}

Human sound phenomena: are directly connected to certain natural phenomena caused by human activity. We can divide them into sound phenomena caused by human tools or activities developed through development of civilization (treating materials with manual or machine tools, electronics, appliances, high technologies...), current state in the field of culture (artistic and scientific activities, system of verbal expression in interpersonal contacts, oral heritage ...) and sound effects specific to humans as living beings (breathing, heartbeat, blood circulation, spatial movement ...).

During the gathering, sorting and preservation of sound materials, special attention should be paid to recognition of sound equivalents. These are sound effects from various sources and categories, which are analysed as similar or comparable. In this case it can be said they are sound associations or similar sounds ${ }^{5}$.

Sound is an element of a certain space and time, not only because of its presence, but also as a reflection of activity and changeability of relations inside and outside of the monitored area; a part of sound enters, invades the monitored area from outside. Sound exists also as a cocreator of properties and co-designer of characteristics and specifics of a researched area, which is in our case Planinsko Polje. It was recorded at the locations around the castle Haasberg, near the cave spring Škratovka, in the hamlet Malni, where they used to have mills, near the spring of Unica, in Planinska Jama cave, Vranja Jama cave, Jama Mačkovica cave, near the Ravbarjev Stolp tower, on Planinska Gora hill, around Jakovica, on Planinsko Polje itself and in the village Planina. Connecting the locations helps create the geometry of space for the spread of sound and its intertwining with other ingredients.

\footnotetext{
${ }^{5}$ M. Adlešič, pp. 710-718
} 
The recording of the materials mentioned in this article $^{6}$ was carried out in one year. So the recordings are in a chronological order: from the sunny and warm September $15^{\text {th }}, 2005$ to the relatively cold and rainy September $15^{\text {th }}, 2006$, with the sound of a roebuck troating in the night of September $20^{\text {th }}, 2006^{7}$ appended. It is of course a very condensed representation of a relatively big sound space, intended more to familiarize people with the sound situation than for intense study and understanding. For a better sound image it would be necessary to integrate the sound into space with a multi-channel system, with a so-called surround sound technique. And it would make sense to continuously inform listeners of the location and the season when the material was recorded. These are our goals for the future ${ }^{8}$.

Through time, sound actually changes the core understanding and purpose of space. For example, in the cemetery near Planina, it is obvious that when it was created, the space was perfect for its purpose if sound is considered; it was an area of relative quiet. Now there is a well travelled road right next to it, a source of aggressive noise; it can be seen as a disturbance in space and a degradation of the original purpose ${ }^{9}$. Of course we cannot treat all sounds introduced by civilization as degradation, but also as the accompanying element of human presence and our activity. We can also speak about degradation when the quantity of sound presence of an activity becomes the prevalent sound element and is as such seen as sound pollution; the sound balance is disrupted. As an example of sound pollution and sound transformation we can list sound events located on the CD Celoletni zvoki Planinskega polja / Sound Properties of Planinsko Polje, appended to the article.

First, the ruins of castle Haasberg, which were the starting point for collecting sound materials. Because of the absence of windows, doors and walls, the presence of exterior sounds is normal; and access into the building (although dangerous) is possible. On

\footnotetext{
${ }^{6}$ attached CD, Celoletni zvoki Planinskega polja, zvočni posnetek št. 1 / Sound Properties of Planinsko Polje, sound track nr. 1

${ }^{7}$ The whole sound archive consists of 7 hours and 12 minutes of sound at $16 \mathrm{bit} / 48 \mathrm{kHz}$. Most of the material is in stereo. The following equipment was used for recording: professional solid state recorder Marantz PMD 660 and microphones Shure VP88, Sony ECM-672 and t.bone EM9900. Sorting and editing materials was carried out on computers Apple with the MOTU 828 mk2, RME Fireface 800 interface and software packages Cubase 3SX, Cubase 4 and Logic Pro 7.2.3. The CD master was prepared with the program WaveBurner.

${ }^{8}$ The task could be executed as a multimedia presentation, whose integral part could be the recording on DVD.

${ }^{9}$ Appended CD, recording nr. 12
}

recording ${ }^{10}$ no. 2 a German shepherd, can be heard freely walking around inside. Because the image of the whole area around the castle changed, domestic animals live there now. We can hear a donkey braying on recording no. 3 . There is an asphalt road running past the castle, on which footsteps (recording no. 4) make a completely different sound than they used to on a dirt road. Below the castle, the river Unica flows, sharing its sound space with traffic on recording no. 5 and with the ringing of remote bells (recording no. 6). At the castle, we can also hear the sounds of the road through the village Planina accompanied by birdsong (recording no. 7). In the hamlet Malni, where they used to have windmills, the sound of their wheels has been replaced by the sound of water in the remaining mill troughs (recording no. 8). Around Ravbarjev Stolp, the pleasant sound of snowmelt dripping from the roof (recording no. 9) is joined by the disturbing buzz of a near-by power plant (recording no. 10). In the village Planina, the sound of carts was replaced by the heavy traffic of motor vehicles (recording no. 11) on the road which also leads past the cemetery near the church (recording no. 12). The evening peace during a sunset at the castle Haasberg is shattered by a remote motorcyclist and a motor plane (recording no. 13); in the middle of Planinsko Polje, the frog concert is joined by a high-flying passenger plane (recording no. 14). Listening to the roebucks near the church above Jakovica, we are constantly reminded of the near-by highway (recording no. 15) and it seems that the primordial sounds can only be found in the embrace of caves. In the Planinska Jama cave we are welcomed by the overwhelming sound of the confluence of the rivers Pivka and Raka (recording no. 16), not far into Vranja Jama we can hear the crowing of crows together with the romantic dripping of water (recording no. 17).

Research of sound demands interdisciplinarity; despite its non-material nature it is an intertwining of both areas of heritage: material and non-material. Since it is necessary to encapsulate the phenomena in the whole of the researched space, including natural phenomena and human activity, we need to originate from the values the space possesses, into which we can plant the gathered materials and establish criteria to give certain types of sounds the status of heritage. It will also be necessary to define the core terminology and gather thoughts and data on sound and its chronological order. In the later process of presenting the collected materials it is the duty

\footnotetext{
${ }^{10}$ All subsequent recordings are located on the CD Celoletni zvoki Planinskega polja / Sound Properties of Planinsko Polje, appended to the article.
} 


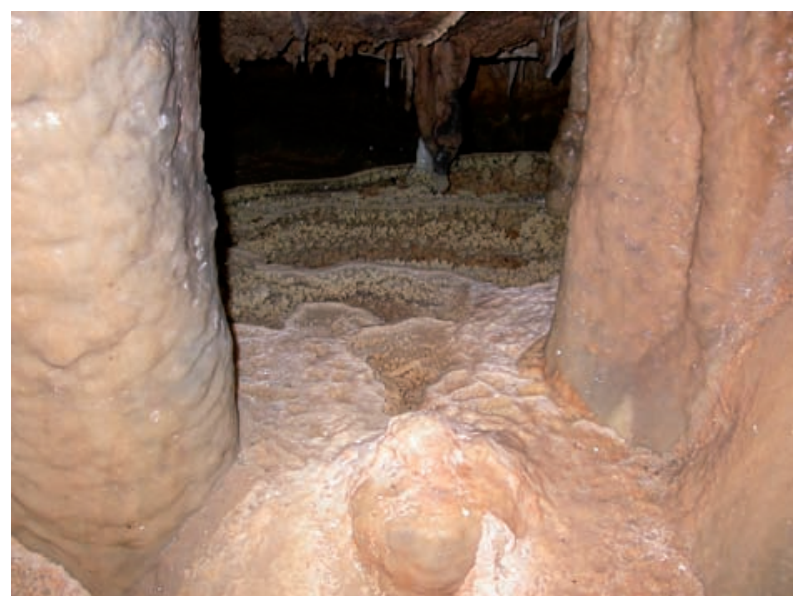

Detail from the cave (Planinska Jama), photo: S. Polak

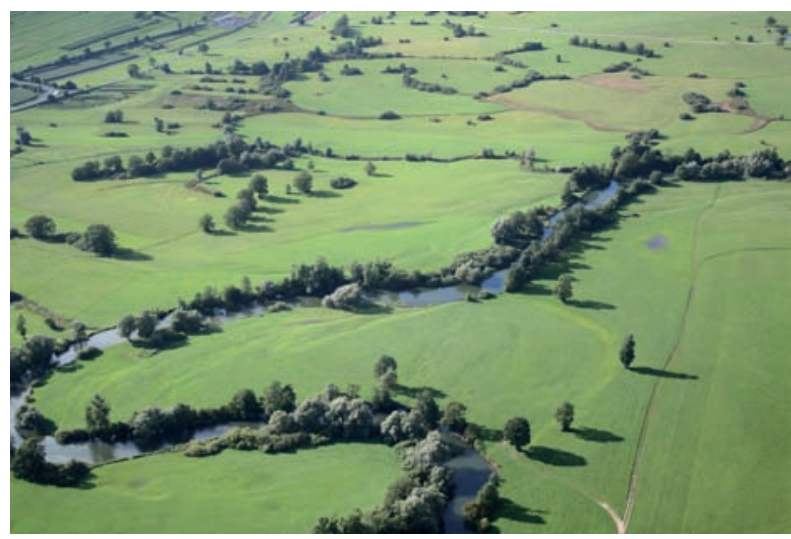

Meandering of river Unica, photo: T. Meze

of the relevant institution to present and interpret results. The presentation can be held in a museum in the traditional style or by creating a virtual space, offering a spatial sound and image presentation.

Reasons for this activity, which at first glance could not be classified as economically beneficial, should be listed or pointed out as well. Usefulness of archiving itself can be seen in its connections with research in the areas of history, art history, ethnology ... even art. The understanding of items and the whole environment itself is done with all the senses. Thus, information about a tool or activity, i.e. at a museum exhibition is not complete without sound. How to explain the workings of a tool or machine and the disrupting impact of its sound on the environment, if the item displayed is small; people often connect physical size with the (non)noisiness of the item. That is very hard to do without a sound illustration, with only technical data.

However, archive sounds are not only a means to turn back the clock. Ordering them in a harmonious series we can create sound-noise compositions, coming alive as new aesthetic forms; old sounds as carriers of information of

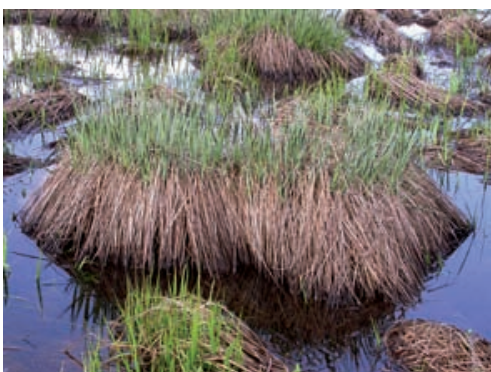

Planinsko Polje, photo: S. Polak
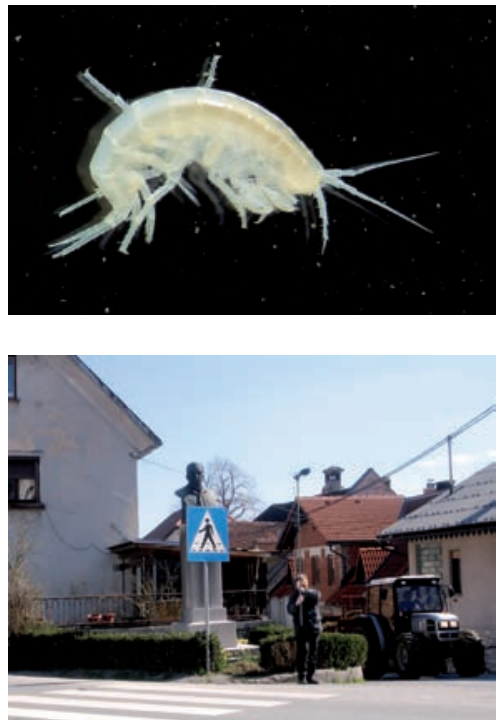

Recording sound in Planina, photo: J. Korošec

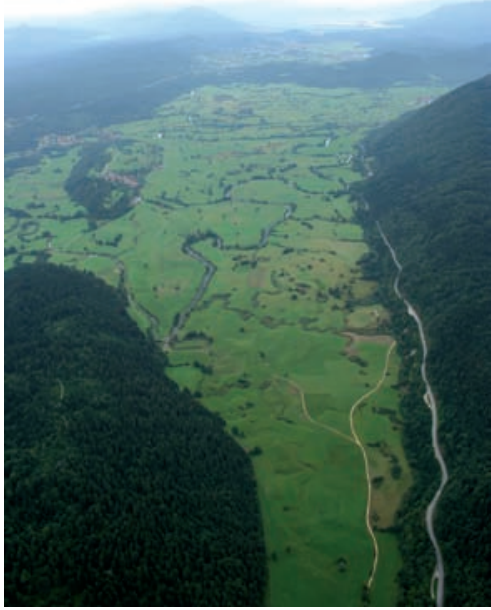

The disappearance of sounds is only one of the aspects of the sound image of our lives. Sounds are constantly changing, as the environment is changing as well. We need to become aware of the fleeting nature of moments we experience. Sounds accompanying an ex- 


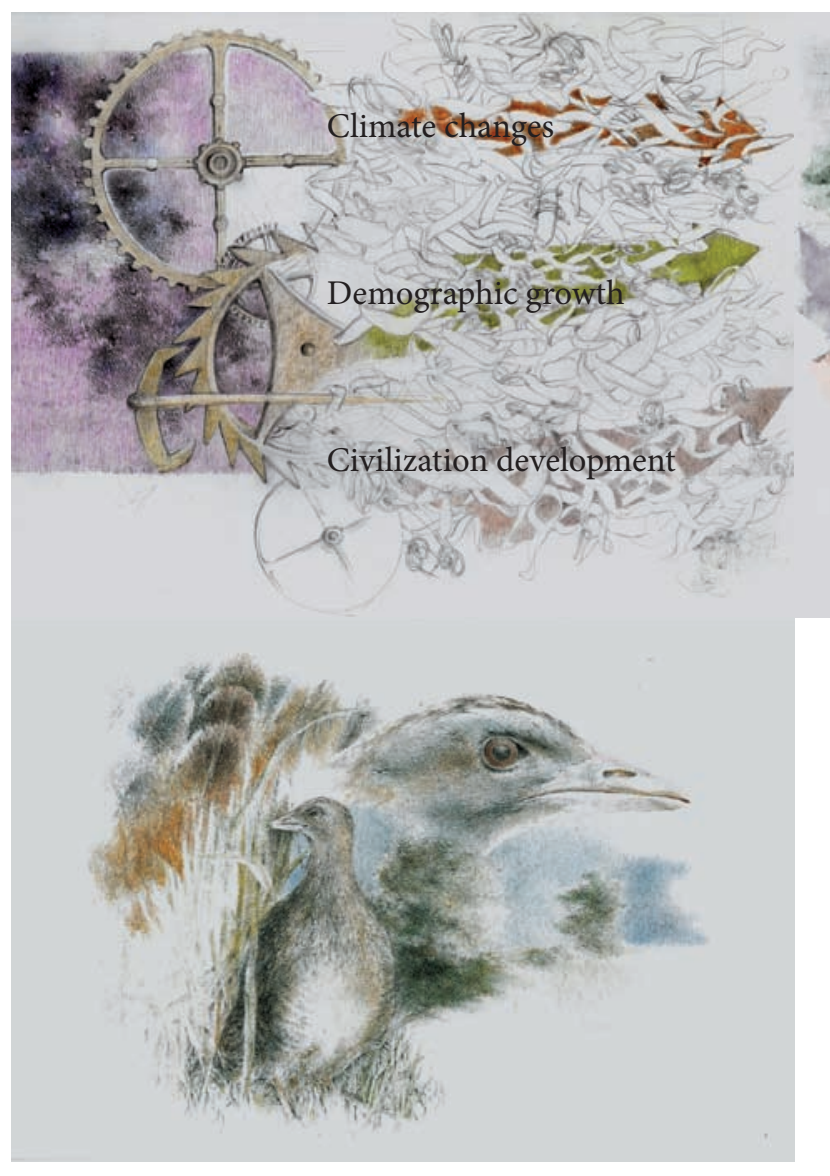

perience are gone first. As a society and state we could prevent that. The project 'Sounds properties of the Karst field Planinsko Polje' is thus only a stone in the mosaic of such endeavours.

Experts consider Planinsko Polje to be a typical example of a polje, nature lovers see it as a pearl of nature, where they return again and again, fishermen see it as a fly fishing paradise, natives see it as land feeding their livestock, a region that silently, almost unnoticeably lives with them. A field with at least four faces: spring, summer, autumn and winter; and at the same time, a field with numerous mysterious sounds.

Planinsko Polje is our most typical polje and seen by various sciences (geology, geomorphology, geography, hydrology, regional architecture, heritage preservation etc.) as an exceptional natural phenomenon of not only national worth but also natural heritage of all humanity. Experts in general see Planinsko Polje as a globally known example of an ideal polje with a high density of classical karstic phenomena in the bottom, on the fringes and in the broader hinterlands. Considering the centuries of the history of karst research in Slovenia, from Valvasor onwards, it could be said that it is a locus classicus' for some karstic phenomena. Due to natural

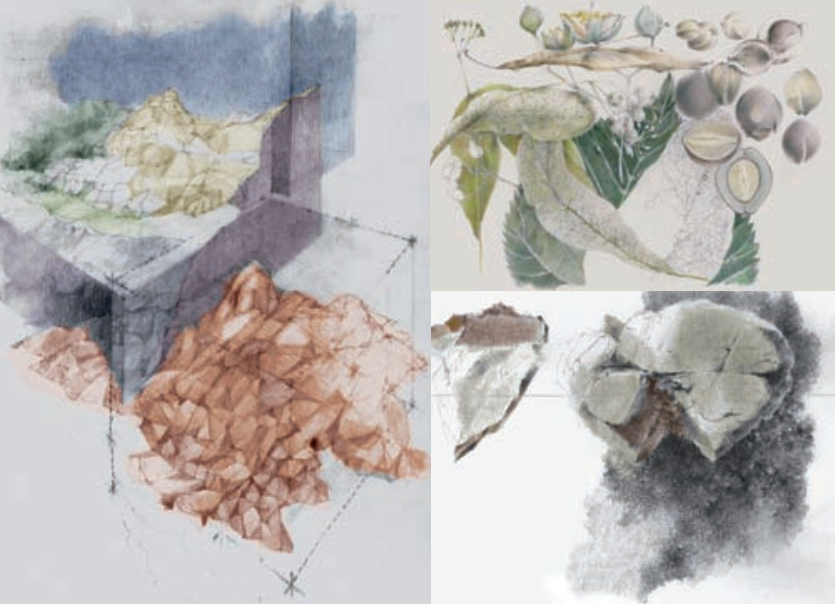

Documentary drawings, global threats:

litho - bio-atmosphere, J. Korošec

Lime blossom, J. Korošec

Natural stone pattern, J. Korošec

Corncrake, J. Korošec

peculiarities and a unique activity of natural processes and the endeavours of many generations of natives to co-naturally manage the space, it is also an exceptional cultural region. Elsewhere in the world, most poljes have been ruined because of anti-flooding measures. Even though it was partially drained, Planinsko Polje as a whole luckily remained relatively preserved and is in this way unique as well. As such, it is a rarity in the whole of the Dinaric world, where such poljes are rare and much degraded. Thus, we support the endeavours to preserve Planinsko Polje with its karstic fringe and caves as a natural monument of state or national importance.

Planinsko Polje is a part of the karstic river basin of Ljubljanica and the north-westernmost in a series of poljes of the river's system. Its altitude is 447 metres above sea level. The area of the polje is $11 \mathrm{~km}^{2}$ and the longer axis, $6 \mathrm{~km}$ long, is in line with the Dinaric direction. This area is the place of the confluence of the river Pivka and water from Cerkniško Polje. The rivers join in Planinska Jama and are seen as a unique example of underground river confluences. Waters of these rivers, which burst out of the earth under a stunning gable in front of Planinska Jama, are henceforth known as river Unica. The field has a prominent influx side with beautiful springs in front of the cave itself and strong influxes Malenščica and torrential Škratovka. Through millennia, the river with its sediments sculpted the Planinska Kotlina Basin into a picturesque and very typical polje. Because its river bed was created in this way, the river Unica meanders in great turns, so its flow is three times longer $(18 \mathrm{~km})$ than Planinsko Polje. 
Especially prominent are the south, western, and north-western fringes of the polje with springs, and eastern and north-eastern with a bunch of sinkholes. The polje does not have surface tributaries, receiving the water from real karstic springs. Floods on Planinsko Polje have become a part of its inhabitants' lives. When the flow of Unica near castle Haasberg rises above 60 $\mathrm{m}^{3} / \mathrm{s}$, the sinkholes are unable to swallow all the water. Unica breaches the banks and spreads across the field. Floods occur several times a year and are most common in late autumn and early spring and last for a few days. Because of the yearly floods the bottom of the field is a more or less natural grass field mostly of the swamp field type with some vegetative peculiarities: meadow squill, blue Siberian iris, red medicinal burnets, purple Illyrian gladioli, to mention only those that give colour to whole meadows. They are often hosts to numerous birds, butterflies and even to 110 species of snails and shells. In numerous caves in Planinsko Polje, there is a rich collection of underground fauna. The most famous case is the human fish (Croteus anguinus).

The symbiosis between cultural and natural heritage, co-created by planned or spontaneous, organized or coincidental processes and phenomena, has changed into a quality recognizable in regularly preserved, exceptionally or generally recognized goods and attractions ${ }^{11}$. They inform us of the historic events, development processes and habits. Relatively small and with a distinctive natural character, Planinsko Polje is defined to such an extent that it would be hard to introduce into it something not subject to existing factors. Precisely because of the size it represented a geographically, strategically useful and active point, interesting to the outside world, and not an area in which different interests and ambitions could be realized. Probably, that is also the cause why even now the inhabitants can decide on such ways of being in Planinsko Polje that show the understanding and the adherence to its properties gained through time.

On the basis of conservatorial and other scientific results and suggestions in international recommendations and legal acts ${ }^{12}$, the research, while gradually dis-

\footnotetext{
${ }^{11}$ Ivan Marušič, Margita Jančič, Kraške krajine notranje Slovenije (Regionalna razdelitev krajinskih tipov Slovenije, 4) (Karstic Regions of Interior Slovenia (Regional Division of Landscape Types of Slovenia, 4), Ministrstvo za okolje, prostor RS, Urad RS za prostorsko planiranje (Ministry of the Environment and Spatial Planning RS, Office for Spatial Planning), Ljubljana 1998

${ }^{12}$ Expert meeting on community involvement in safeguarding intangible cultural heritage: Towards the implementation of the 2003 convention (13-15 March 2006, Tokyo), Intangible Heritage Section, UNESCO 2006
}

covering individual facts, is mostly focused on the area of connections between the material and non-material and between the natural and the cultural. It is a basic quality and a moderator of existing processes. Most of the prominent carriers of such properties of the protected area are in the south-western part of Planinsko Polje, where the morphology of the relief and the strategy of work caused the activities to condense; now they are spreading to the other areas in accordance with the regional image, allowing natural phenomena to be even more independent.

Thus, the dialogue between the market Planina, which is urbanistically organized in two parallels along the regional road, and castle Haasberg, the historically and economically based complex ${ }^{13}$, gave birth to a functional and imaginary triangle, into whose frame all the key factors of both agglomerations fit. The presence of the river Unica, which functions as a belt, created mostly by nature and its phenomena, is a border between them and at the same time an equal ingredient of the ${ }^{14}$. Morphologically, Planina, called Alben in the Middle Ages, was created by transport, the core activity of the ancient road connection of Ljubljana and Postojna and the wider south western area. Before the demanding mountain pass 'Postojna Gate' it split into the old presumably Roman route towards Predjama, Nanos and the Littoral; and the one that goes from Haasberg castle towards Unec, Rakek and Cerknica.

The final point of the triangle is the preserved, round Ravbarjev Stolp tower, the remains of the medieval, well-fortified Mali Grad castle. It was placed above the entrance to Planinska Jama cave and after several owners it at last became property of the Haasberg gentry. Culturally, it is the most prominent ingredient of Planinsko Polje.

Today more of a trace of the previous subject, the castle started its developmental journey, in accordance with the dangers of medieval times and relevance of previous experience, on the top of a hill as a fortified castle. Because of the changes in the way of life and with the factors which are a constant in forming the regional im-

Miroslav Adlešič, Svet zvoka in glasbe (2. knjiga), svet žive fizike, zbirka Priroda in ljudje (World of Sound and Music (2nd book), World of Living Physics, collection Nature and People), Mladinska knjiga, Ljubljana 1963

${ }^{13}$ Nataša Štupar - Šumi, Dvorec Planina (Haasberg) pri Rakeku, Varstvo spomenikov 28 (Manor Planina (Haasberg) near Rakek), Zavod RS za varstvo naravne in kulturne dediščine (Institute for the Protection of Cultural Heritage of Slovenia), Ljubljana 1986, pp. 89-100

${ }^{14}$ Vodno bogastvo Slovenije (Water Wealth of Slovenia), Ministrstvo za okolje, prostor in energijo, Agencija RS za okolje (Ministry of the Environment, Spatial Planning and Energy, Environment Agency), Ljubljana 2003 

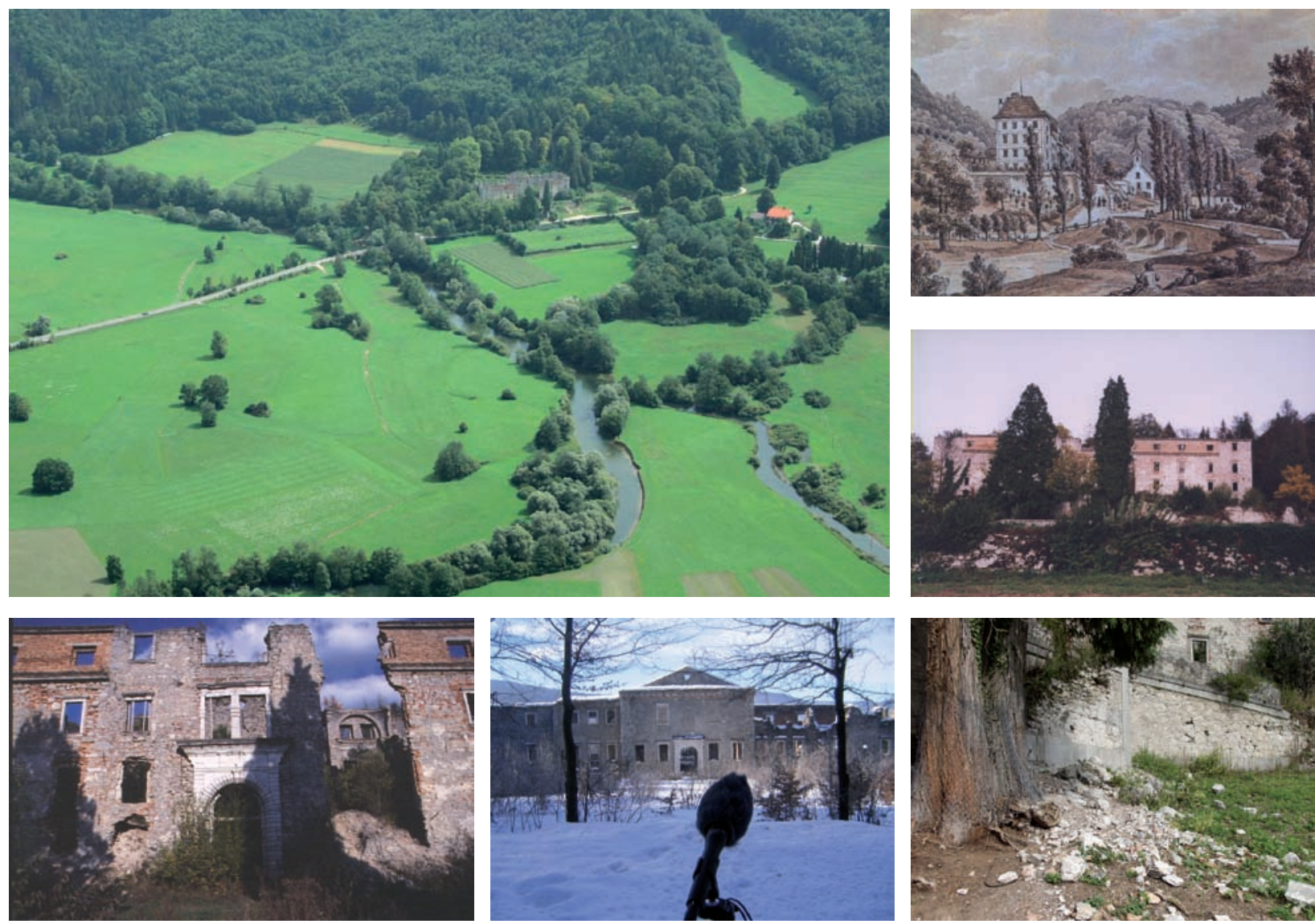

Aerial photo of the SE Art of Planinsko Polje, photo: T. Meze

Castle Haasberg, photo: M. Korošec

Castle Haasberg, photo: B. Perovšek

age, it obtained its final shape as a representative building in the beginning of the $18^{\text {th }}$ century, when the estate was owned by the family Cobencel, it was build on an axis, precisely pointing across the terraced descent into the valley to Ravbar Tower and entrance to Planinska Jama cave.

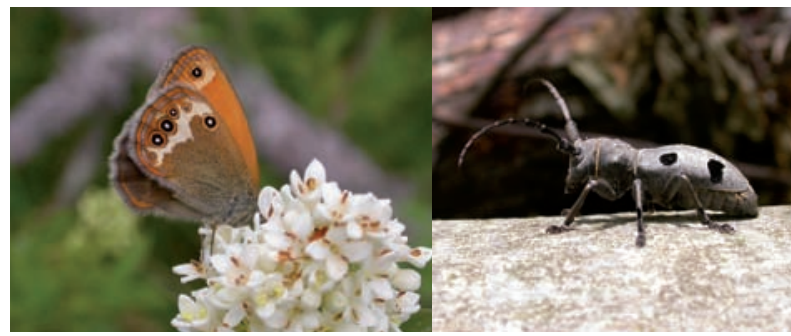

Coenonympha arcania, photo: S. Polak

Morimus funereus, photo: S. Polak

An actual support for building and park architecture, the tower was the essential connection of remote
Wet-canvas drawing, by: Franz Kurz,

Haasberg through time, photo: M. Korošec,

Haasberg today - detail, photo: M. Korošec

points into an organized system. Both components, the natural and the artificial, became humanized into a har-

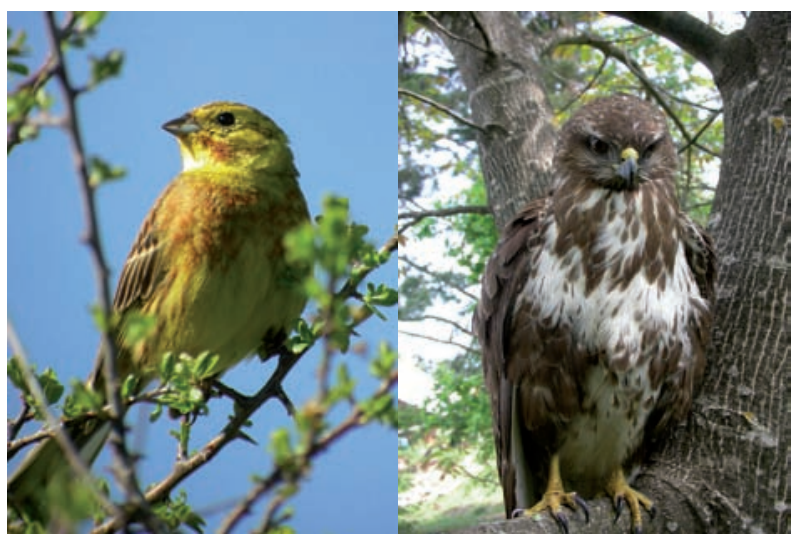

Buzzard, photo: L. Kebe

Yellowhammer, photo: L. Kebe

monic whole in this system despite the extravagance of the architecture. Thus the roof of the castle building could 
protect all the peculiarities of aristocratic life which was seen as generally accepted by the environment, mostly because of the thoughtful and continuously upgraded attitude towards nature, i.e. water, the crucial ingredient of developed ambiences, besides its picturesque looks enhanced by the karstic phenomena, moisture and sound also supplied economic structures, such as mills, saws and such with energy. The things produced by the creativity of gardeners enhanced with imagination, such as the variety of gardens or individual rock formations, were already naturally supplied by the environment. We should not forget the environment, not only bordering but also entering the castle area with its vegetation and flora, showing its existence in non-material terms as well. The physical connection among the established objects and Trg Planina market was provided by the road perpendicular to the axis and leading towards the settlement and the one following the edges of the valley towards former work buildings and Malni and so on.

Less geometrically strict, but no less welcoming are the rural settlements Laze, Grčarevec and Jakovica and other hamlets and individual farms, placed on the rises and the terraced fringe.
Described, some only partially preserved values, forming a cultural ingredient of heritage, do not threaten nature and its existence with their presence. Furthermore, research shows that in Planinsko Polje both are equal and thus prove the importance of harmony in such a space as a quality that needs protection. Similarly, all those values included in the notion of non-material heritage should be protected as well, even though the field is only now receiving a more complex scientific treatment in Slovenia. Thus, the sound recordings in Planinsko Polje start an analysis of its basic presence, about the types of its manifestations and the role it has as an indicator of relations between individual carriers and the degree of endangerment, especially that caused by the environment outside the studied area.

Undoubtedly, the systematic recording of sound is a way of documenting certain heritage types and a form of preserving its non-material properties. Simultaneously, it is a tool which can more prominently contribute to prevention and help with protection measures. Furthermore, the existing and anticipated relations dictate a more complete use of the dimensions of sound for general prevention purposes.

\section{LITERATURE}

Tanja Žigon, 1997: Planinsko Polje, publishing house Tuma d.o.o., Ljubljana,

Rado Smerdu, 1979: Planinsko polje kot del najpomembnejše dediščine Slovenije (Planinsko Polje as part of Slovenia's most important heritages), Varstvo narave št. 12 (Nature Protection, issue 12), Ljubljana,
Slavko Polak, 2006: Opazovanje ptic, Priročnik za opazovanje ptic na izbranih območjih Notranjske, krasa in obale (Manual for Bird Watching on Selected Areas of Notranjska, the Karst and the Littoral), Postojnska jama, turizem d.d., Postojna,

Drago Kolenc, 2006: Dober dan, Krpanova dežela (Good Morning Land of Krpan), Notranjsko kraški regionalni zavod za turizem Postojna in Postojnska jama, turizem d.d., Postojna,

Pobuda za zaščito Planinskega polja Slovenskega geološkega društva in Geomorfološkega društva Slovenije (Initiative to Protect Planinsko Polje by the Slovenian Geological Society and the Geomorphological Society of Slovenia) 